\title{
Advances in the kinetic and dynamic kinetic resolution of piperazine-2-carboxylic acid derivatives with Candida antarctica lipase A; structural requirements for enantioselective $\mathbf{N}$-acylation
}

\author{
Ari Hietanen, Katri Lundell, Liisa T. Kanerva, and *Arto Liljeblad \\ Institute of Biomedicine, Department of Pharmacology, Drug Development and Therapeutics / \\ Laboratory of Synthetic Drug Chemistry and Department of Chemistry, University of Turku, \\ Lemminkäisenkatu 5 C, FIN-20520, Turku, Finland \\ E-mail: artlilje@utu.fi
}

Dedicated to Professor Ferenc Fülöp on his $60^{\text {th }}$ birthday

\begin{abstract}
The kinetic resolution of piperazine-2-carboxylic acid was studied as its $\mathrm{N}$-4- and $\mathrm{N}$-1-Bocpiperazine-2-carboxylic acid methyl esters, $r a c-1$ and -2, respectively. Lipase A from Candida antarctica (CAL-A) catalyzed highly enantioselective ( $E>200$ for $r a c-1$ and 200 for rac-2) Nacylation of both compounds with 2,2,2-trifluoroethyl butanoate in TBME. Aldehyde-based dynamic kinetic resolution of $r a c-1$ with vinyl butanoate in acetonitrile gave up to $75 \%$ product yield with $S$-absolute configuration in 48 hours. The present results together with literature data suggest that CAL-A - catalyzed $\mathrm{N}$-acylation is enhanced in terms of reaction rate or enantioselectivity when an electron rich structure, such as carboxylic ester or aromatic ring, is attached to the asymmetric center next to the secondary ring nitrogen.
\end{abstract}

Keywords: Candida antarctica lipase A, CAL-A, kinetic resolution, dynamic kinetic resolution, $\mathrm{N}$-acylation, piperazine-2-carboxylic acid

\section{Introduction}

Piperazine-2-carboxylic acid (A, Scheme 1) is a valuable building block and constituent of many current and potential drug molecules. Such molecules include antagonists for $N$-methyl-Daspartic acid (NMDA) type glutamate receptors ${ }^{1}$, indinavir ${ }^{2}$ used to treat HIV infections and inhibitors for TNF- $\alpha$ converting enzyme (TACE) ${ }^{3}$ and farnesyl protein transferase ${ }^{4}$. Various methods have been developed for the preparation of the enantiomers of piperazine-2-carboxylic acid. In addition to traditional crystallization of diastereomeric salts, ${ }^{5}$ kinetic resolution (KR) methods based on the enzymatic hydrolysis of an ester or amide functionality at the 2-position of 
the piperazine ring exist (Scheme 1). Thus, hydrolyses of piperazine-2-carboxamide by L-leucine aminopeptidase $(\mathrm{B})^{6}$ and amidases $(\mathrm{C})^{7}$ in a bacterial whole cell system have been developed. Moreover, $(R)$ - and $(S)$-specific amidases, hydrolyzing piperazine-2-tert-butylcarboxamides (D), have been isolated, 8,9 and alcalase (Bacillus licheniformis protease) has been reported to hydrolyze 4-tert-butoxycarbonylpiperazine-2-carboxylic acid methyl ester $(\mathrm{E})^{10}$. Both enantiomers can be obtained by the KR of a racemate. However, dynamic kinetic resolution (DKR) methods, usually combining KR with the in situ racemization of the less reactive enantiomer, have been considered preferable as in the best case a racemate can be transformed into one enantiomer with $100 \%$ yield. Methods based on the DKR of piperazine-2-carboxylic acid or its derivatives have not been published so far. In addition to KR and DKR methods, deracemization is an interesting third option applied to transform D,L- $\alpha$-amino acids like piperazine-2-carboxylic acid (A) into the L-enantiomer with D-amino acid oxidase. ${ }^{11}$<smiles>O=C(O)[C@H]1CNCCN1</smiles>

deracemization by D-amino acid oxidase ( $99 \%$ ee, $86 \%$ yield)<smiles>C=CC(N)=O</smiles>

hydrolysis by

Burkhold eria DSM 9925 $\left(99.0 \% \mathrm{ee}_{\mathrm{p}}, 22 \%\right.$ yield $)$<smiles>CC(Br)(OC(=O)N1C=C(C(N)=O)NCC1)c1ccccc1</smiles>

hydrolysis by

L-leucine aminopeptidase $\left(82 \% \mathrm{ee}_{\mathrm{s}}, 67 \% \mathrm{ee}_{\mathrm{p}}\right)$<smiles>C=CC(=O)NC(C)(C)C</smiles>

hydrolysis by

- $(R)$-amidase from

Pseudomonas sp. MCI3434

- (S)-amidase from Pseudomonas azotof ormans IAM1603

In both cases enantiospecific reactions were reported.<smiles>C=CC(C(N)=O)C1CNCCN1</smiles>

hydrolysis by

Klebsiella DSM 9174

(99.4\% ee, $41 \%$ yield) or

Pseudomonas DSM 9924

(97.3\% ee , 20\% yield)<smiles>CCC(C)(C)OC(=O)C1CN(C(=O)c2ccccc2)CCN1</smiles>

hydrolysis by

alcalase from

Bacillus licheniforms

$\left(82 \% \mathrm{ee}_{\mathrm{s}}, 67 \% \mathrm{ee}_{\mathrm{p}}\right)$

Scheme 1. Biocatalytic preparation of piperazine-2-carboxylic acid derivatives of high enantiopurity. The more reactive enantiomer has been presented. ${ }^{6-11}$

In this paper, we have studied the possibility to resolve racemic piperazine-2-carboxylic acid methyl ester with Candida antarctica lipase A (CAL-A) relying on the previously established Nacylation method for proline and pipecolic acid methyl esters. ${ }^{12 a, b}$ However, piperazine-2carboxylic acid methyl ester with two secondary amino groups provides two N-acylation sites, making the KR challenging. Accordingly, we decided to study one $\mathrm{N}$-acylation in time, the other 
nitrogen being Boc-protected (rac-1 and -2; Scheme 2). We have also studied the possibility to transform the KR of rac-1 into DKR using the previously described aldehyde-based in situ racemization of the less reactive $(R)-\mathbf{1}$ (Scheme 3 ). ${ }^{12 \mathrm{~b}}$ It is worth noting that the DKR of rac-2 by the same method unlikely takes place since the N-acylation position is not directly attached to the asymmetric centre. We finally consider the results obtained in this work and found in literature to establish structural requirements for the CAL-A -catalyzed secondary N-acylations of heterocyclic amines. Additionally, purification of CAL-A from a glycerol solution of Novozym 735 and its immobilization as a CAL-A on Celite preparation is described.

Lipase A from Candida antarctica (CAL-A) has proven to own many interesting and exceptional properties usable in synthetic applications. ${ }^{13}$ Related to the present study, CAL-A catalyzes highly enantioselective $\mathrm{N}$-acylations of various $\alpha$ - and $\beta$-amino esters and, atypically to most lipases, $\mathrm{N}$-acylations of several secondary amines. ${ }^{12}$ This can be explained by the wide nucleophile binding site of the enzyme. According to the crystal structure of CAL-A and molecular modeling, CAL-A has been proposed to undergo a conformational change upon substrate binding, where the active-site "flap" (Gly426-Gly440) moves around the active site, widening the available space large for the nucleophile to be bound. ${ }^{14}$ On the other hand, the acyl binding pocket is long and narrow, making the enzyme to prefer long-chain carboxylic acid derivatives as acyl donors.

\section{Results and Discussion}

\section{Kinetic resolution}

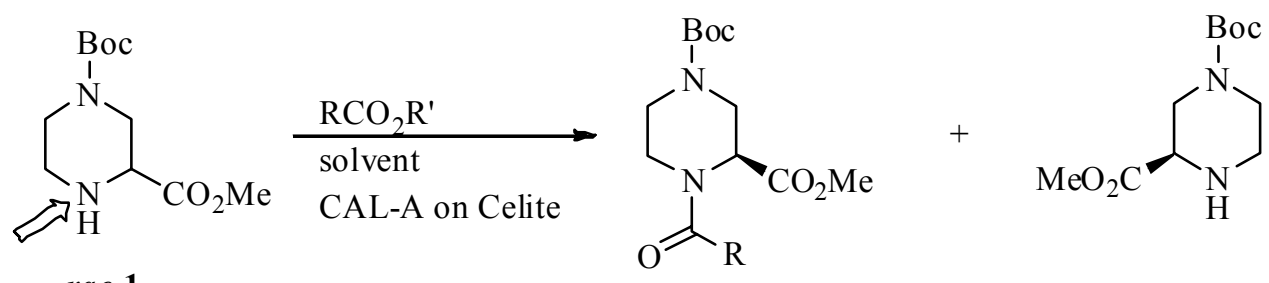

(S)-3

(R)-1

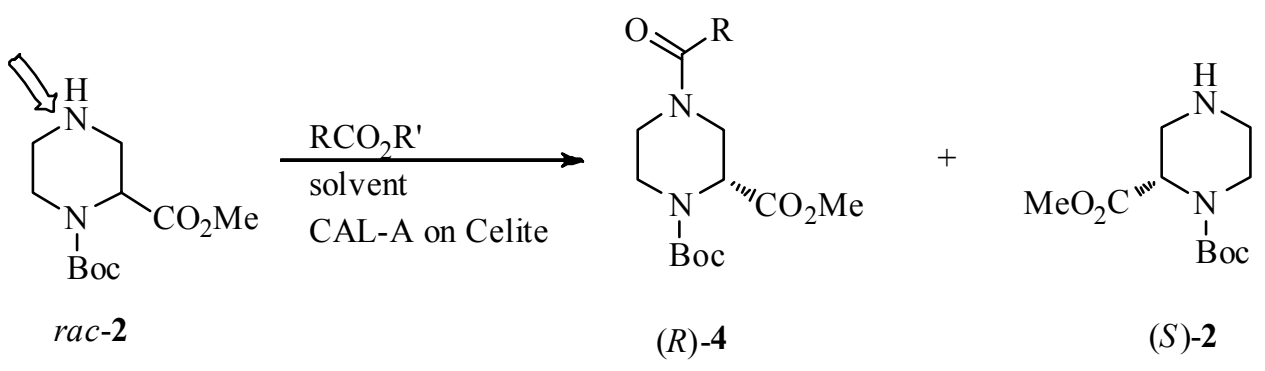

Scheme 2. Enantioselective N-acylation of $\mathrm{rac}-\mathbf{1}$ and -2 with CAL-A. 
The kinetic resolution of 4- and 1-N-Boc-protected rac-1 and -2 was studied with 2,2,2trifluoroethyl, vinyl and ethyl esters in diisopropyl ether (DIPE) and tert-butyl methyl ether (TBME) in the presence of CAL-A (Scheme 2). The KR studies were performed using Novozym 735 -based CAL-A on Celite preparation prepared as described in the Experimental Section.

Table 1. CAL-A ${ }^{\mathrm{a}}$-catalyzed $\left(25 \mathrm{mg} \mathrm{mL}^{-1}\right) \mathrm{N}$-acylation of rac-1 and $\mathbf{- 2}(0.050 \mathrm{M})$ with various acyl donors $(0.100 \mathrm{M}$; $\mathrm{t}=60 \mathrm{~min})$

\begin{tabular}{|c|c|c|c|c|c|c|c|}
\hline Entry & Substrate & Acyl donor & Solvent & $\mathrm{c}(\%)$ & $\mathrm{ee}_{\mathrm{s}}(\%)$ & $\mathrm{ee}_{\mathrm{p}}(\%)$ & $E$ \\
\hline 1 & $r a c-1$ & $\begin{array}{c}\text { 2,2,2-trifluoro- } \\
\text { ethyl acetate }\end{array}$ & DIPE & 6 & 6 & $>99$ & $>200$ \\
\hline 2 & $r a c-1$ & $\begin{array}{l}\text { 2,2,2-trifluoro- } \\
\text { ethyl butanoate }\end{array}$ & DIPE & 50 & $>99$ & $>99$ & $>200$ \\
\hline 3 & $r a c-1$ & $\begin{array}{l}\text { 2,2,2-trifluoro- } \\
\text { ethyl butanoate }\end{array}$ & TBME & 47 & 88 & $>99$ & $>200$ \\
\hline 4 & $r a c-1$ & ethyl butanoate & TBME & 6 & 6 & $>99$ & $>200$ \\
\hline 5 & $r a c-1$ & vinyl butanoate & TBME & 48 & 93 & $>99$ & $-{ }^{b}$ \\
\hline 6 & $r a c-1$ & vinyl acetate & TBME & 2 & 2 & $>99$ & $-\mathrm{b}$ \\
\hline 7 & $r a c-2$ & $\begin{array}{c}\text { 2,2,2-trifluoro- } \\
\text { ethyl acetate }\end{array}$ & DIPE & 6 & 6 & $>99$ & 45 \\
\hline 8 & $r a c-2$ & $\begin{array}{l}\text { 2,2,2-trifluoro- } \\
\text { ethyl butanoate }\end{array}$ & DIPE & 23 & 30 & $>99$ & 140 \\
\hline 9 & $r a c-2$ & $\begin{array}{l}\text { 2,2,2-trifluoro- } \\
\text { ethyl butanoate }\end{array}$ & TBME & 16 & 18 & $>99$ & 200 \\
\hline 10 & $r a c-2$ & ethyl butanoate & TBME & $<1$ & $<1$ & $>99$ & $-^{\mathrm{c}}$ \\
\hline
\end{tabular}

${ }^{a}$ CAL-A isolated by dialysis from Novozym 735 and immobilized on Celite in the presence of sucrose as described in the Experimental Section. ${ }^{b}$ not calculated; racemization of $(R)-1$ is possible due to released acetaldehyde. ${ }^{c}$ not detected.

As expected on the basis of our previous studies for the $\mathrm{N}$-acylations of proline and pipecolic acid esters, ${ }^{12 \mathrm{a}, \mathrm{b}}$ the KR of $\mathrm{rac}-\mathbf{1}$ (an $\alpha$-amino ester) with all acyl donors tested took place with exquisite enantioselectivity $(E>200)$, the $S$-enantiomer being the reactive one (Table 1; entries 1-6). On the other hand, $\mathrm{N}$-acylations proceeded efficiently only when alkyl-activated (trifluoroethyl or vinyl) esters were used as acyl donors (compare entries 2, 3 and 5 to 4). Additionally, despite activated alkyl part, corresponding reactions with acyl donors based on acetate as a short-chain carboxylic acid took place slowly (compare entries 1 to 2 and 5 to 6). It is worth noting that vinyl esters give vinyl alcohol as another product of enzymatic $\mathrm{N}$-acylation, leading to acetaldehyde as a spontaneous decomposition product. This causes a risk for imine (Schiff base) formation between $\mathbf{1}$ and acetaldehyde and, accordingly, a risk for reduced 
enantiomeric excess values ( $\left(e_{S}\right)$ of the unreacted substrate enantiomer. For this reason $E$ values are not given when vinyl esters have been used as acyl donors (entries 5 and 6).

The $\mathrm{N}$-acylation of rac-2 (a $\beta$-amino ester) proceeded considerably slower (Table 1; entries 7-10), and the reaction in DIPE displayed clearly lower enantioselectivity (entries 7 and 8) than the reaction of $\mathrm{rac}-\mathbf{1}$ under the same conditions (entries 1 and 2). Excellent enantioselectivity for rac-2 $(E=200)$ was detected only in the reaction with 2,2,2-trifluoroethyl butanoate in TBME (entry 9). However, with extended reaction time signs of the formation of the other enantiomer appeared in the HPLC chromatogram (ee $98 \%$ at $42 \%$ conversion after $6 \mathrm{~h}$ ), whereas ee $>$ p $>99 \%$ was detected with rac-1 even after $24 \mathrm{~h}$, indicating higher enantioselectivity in the latter case. Interestingly, opposite enantiomers reacted with CAL-A in the N-acylations of rac-1 and -2. The determination of the reactive enantiomer $(S)-\mathbf{3}$ is based on the optical rotation as described in the Experimental Section. The $S$-enantiopreference of CAL-A is also in accordance with the Nacylations of proline and pipecolic acid methyl esters. ${ }^{12 \mathrm{a}, \mathrm{b}}$ Commercial $(R)-2$ as a reference compound indicated $(R)-2$ to be the reactive enantiomer.

In order to show the synthetic value of the kinetic resolution method, rac-1 was subjected to gram-scale KR with 2,2,2-trifluoroethyl butanoate in TBME. When the reaction was stopped at 50\% conversion, $(R)-1$ (ee=99\%) and $(S)-3$ (ee $>99 \%)$ were successfully isolated by column chromatography. In the same way, the enantiomers of rac-2 can be separated in a preparative scale. However, it is not possible obtain both $(R)-\mathbf{4}$ (ee $\mathrm{e}_{\mathrm{P}}=98 \%$ at $42 \%$ conversion) and $(S)-2$ ( $\mathrm{ee}_{\mathrm{S}}=97 \%$ at $52 \%$ conversion) at high enantiopurities in a single resolution step. Accordingly, the gram-scale resolution of $\mathrm{rac}-\mathbf{2}$ was not performed here.

\section{Dynamic kinetic resolution}

Dynamic kinetic resolution of amines can be achieved by using aldehydes, ${ }^{12 b, 15}$ metals, ${ }^{16}$ radical initiators ${ }^{17}$ or enzymes ${ }^{18}$ as racemization catalysts in an enzymatic kinetic resolution mixture. As the kinetic resolution of $\mathrm{rac}-\mathbf{1}$ with vinyl butanoate proceeded with excellent enantioselectivity, producing the corresponding $(S)$-3 with high efficiency (Table 1, entry 5), we found it interesting to subject $r a c-1$ to the previous simple and inexpensive DKR conditions ${ }^{12 \mathrm{~b}}$. According to this method, vinyl butanoate is used as an acyl donor for the $\mathrm{N}$-acylation of the secondary amino group of an N-heterocyclic $\alpha$-amino ester. Hence, no added aldehyde is needed for the racemization of the unreacted enantiomer, because in the formation of the N-acylated product (S)-3 or -6 the vinyl alcohol released from the acyl donor (vinyl butanoate) is isomerized in situ into the racemization agent acetaldehyde (Scheme 3). Acetaldehyde can be also formed by enzymatic hydrolysis of vinyl butanoate by enzyme-bound water. Hydrolysis also yields butanoic acid which may further form salt $\mathbf{1 0}$ with the starting material.

It is astonishing that with $\mathrm{N}$-heterocyclic $\alpha$-amino esters like $\mathrm{rac}-\mathbf{1}$ (or rac-5) the formation of the intermediate Schiff base $\mathbf{8}$ is reversible under the mild enzymatic reaction conditions, since generally the hydrolysis of a Schiff base requires acidic conditions at elevated temperatures. ${ }^{19}$ Although the exact racemization mechanism is not established, we propose that the acidic $\alpha$-hydrogen at the asymmetric centre is involved in the racemization through the 
formation of $\mathbf{8}$. As a support to this, the calculated $\mathrm{p} K_{\mathrm{a}}$ values of the $\alpha$-protons of $\mathrm{rac}-\mathbf{1}, \mathbf{7}(\mathrm{Y}=N$ Boc) and 8 ( $\mathrm{Y}=N$-Boc) decrease in the order of 23.2, 21.9 and 17.9, respectively, while the corresponding $\mathrm{p} K_{\mathrm{a}}$ values for rac-5, $7\left(\mathrm{Y}=\mathrm{CH}_{2}\right)$ and $\mathbf{8}\left(\mathrm{Y}=\mathrm{CH}_{2}\right)$ are 24.8, 23.5 and 19.4. ${ }^{20}$ As a support to the calculated descending trend, the iminium ion formation has been experimentally shown to correspond to the effect of $7 \mathrm{p} K_{\mathrm{a}}$ units when the $\alpha$-proton of glycine methyl ester is compared to that of the iminium ion. ${ }^{21}$

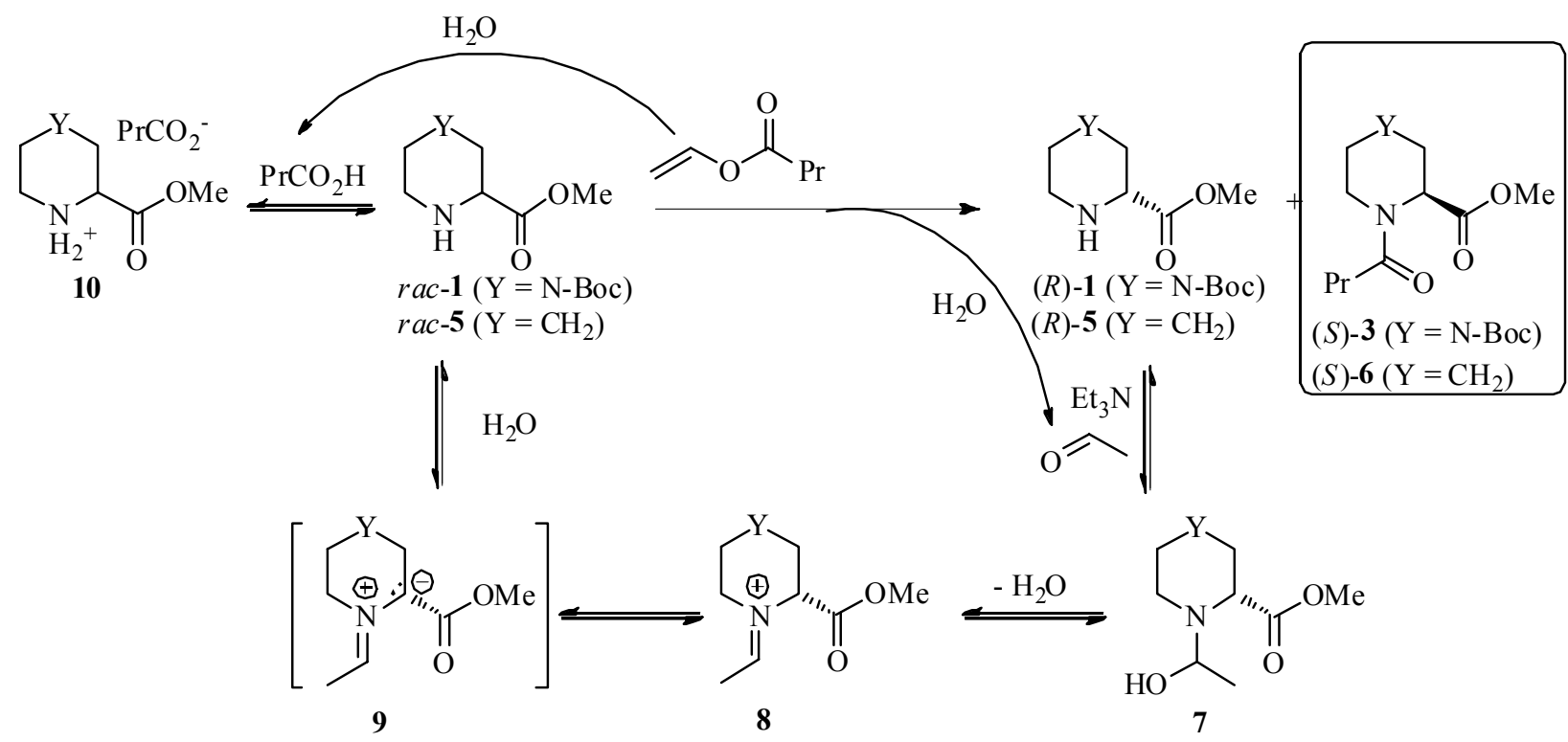

Scheme 3. DKR of rac-1 and rac-5.

When rac-1 was subjected to acylation with vinyl butanoate by Novozym 735-based CAL-A on Celite under the previous DKR conditions ${ }^{12 b}$ disappointing results were observed (the results not shown herein). Thus, the aldehyde-based racemization step seemed to be slow compared to the KR step, and the enzymatic N-acylation had virtually stopped while slightly racemized starting material 1 was still present. In the previous work, lyophilized Chirazyme L5 powder (former SP 526 from Novo Nordisk) rather than aqueous glycerol solution (Novozym 735) needing dialysis before adsorption on Celite was used. Possibly the Novozym 735 -based CALA on Celite (although perfectly worked in the KR, Table 1) was not in the same stable stage as the earlier Chirazyme L5 -based preparation had been. For this reason, the DKR of pipecolic acid methyl ester rac-5 was reinvestigated with different CAL-A preparations in TBME (Table 2 , entries 1-5 and 7). Indeed, the previously observed $61 \%$ product yield with Chirazyme L5based preparation $^{12 \mathrm{~b}}$ and the disappearance of the substrate at this stage (entry 6) were not achieved with the Novozym 735-based CAL-A preparation (entry 3), confirming different behaviors of the two enzyme preparations. The DKR results of rac-5 with other CAL-Apreparations, CLEA (cross-linked enzyme aggregate) and covalently immobilized CAL-A-T2150 (entries 1 and 2), did not give better results either, and the reactions stopped at early 
conversions. Interestingly, the DKR of rac-5 with Novozym 735 -based CAL-A on Celite in acetonitrile allowed the preparation of $(S)-6$ at $60 \%$ yield (entry 7 ), although even then still 10\% of slightly enantiomerically enriched 5 was present in the reaction mixture. The difference between the reactions in TBME (entry 3) and acetonitrile (entry 7) may reflect for instance solubility differences of the ammonium salt $\mathbf{1 0}$ between the amino ester substrate and butanoic acid into these solvents.

Finally, the N-acylation of $r a c-1$ in acetonitrile was studied with three different CAL-Aimmobilizates (Novozym 735-, Chirazyme L5- and lyophilized Cat\#ICR-112-based) on Celite (entries 8-10). As with rac-5 (entry 7), the product yields reached the levels of 59-75\%. Moreover, $r a c-1$ was transformed into $(S)$-3 with excellent enantiopurity (ee>99\%). However, also for the reaction in acetonitrile considerable amount of the unreacted substrate $(24 \%$, ee $7 \%$, entry 8) stayed in the reaction mixture with Novozym 735 -based CAL-A on Celite, indicating that this preparation is less stable than the other commercial enzyme powders under the DKR conditions (entries 9 and 10).

Table 2. Acylation of $r a c-1(0.050 \mathrm{M})$ and $r a c-5(0.100 \mathrm{M})$ with vinyl butanoate (4 equiv.) by CAL-A preparations $\left(50 \mathrm{mg} \mathrm{mL} \mathrm{mL}^{-1}\right.$ for rac-1; $75 \mathrm{mg} \mathrm{mL}{ }^{-1}$ for rac-5) in the presence of triethylamine (1 eq.) at $48^{\circ} \mathrm{C}(\mathrm{t}=48 \mathrm{~h})$

\begin{tabular}{|c|c|c|c|c|c|c|c|}
\hline \multirow[t]{2}{*}{ Entry } & \multirow[t]{2}{*}{ Substrate } & \multirow{2}{*}{$\begin{array}{c}\text { CAL-A } \\
\text { preparation }\end{array}$} & \multirow[t]{2}{*}{ solvent } & \multicolumn{2}{|c|}{ Substrate } & \multicolumn{2}{|c|}{ Product } \\
\hline & & & & $\mathrm{ee}_{\mathrm{s}}(\%)$ & $\begin{array}{l}\text { Yield } \\
(\%)\end{array}$ & $e_{p}(\%)$ & $\begin{array}{l}\text { Yield } \\
(\%)^{\mathrm{a}}\end{array}$ \\
\hline 1 & $r a c-5$ & CAL-A-T2-150 & TBME & 3 & 10 & 98 & 43 \\
\hline 2 & $r a c-5$ & CAL-A-CLEA & TBME & 3 & 34 & 95 & 19 \\
\hline 3 & $r a c-5$ & CAL-A on Celite ${ }^{\mathrm{b}}$ & TBME & 7 & 13 & 98 & 48 \\
\hline 4 & $r a c-5$ & CAL-A on Celite & $\begin{array}{c}\mathrm{TBME}+3 \AA \\
\text { mol. sieves }\end{array}$ & 62 & 42 & 97 & 45 \\
\hline 5 & $r a c-5$ & CAL-A on Celite & $\begin{array}{l}\text { TBME }+4 \AA \\
\text { mol. sieves }\end{array}$ & 70 & 14 & 97 & 26 \\
\hline 6 & $r a c-5$ & CAL-A on Celite ${ }^{c}$ & TBME & - & - & 97 & 61 \\
\hline 7 & $r a c-5$ & CAL-A on Celite ${ }^{\mathrm{b}}$ & $\mathrm{CH}_{3} \mathrm{CN}$ & 6 & 10 & 98 & 60 \\
\hline 8 & $r a c-1$ & CAL-A on Celite ${ }^{\mathrm{b}}$ & $\mathrm{CH}_{3} \mathrm{CN}$ & 7 & 24 & $>99$ & 59 \\
\hline 9 & $r a c-1$ & CAL-A on Celite ${ }^{\mathrm{d}}$ & $\mathrm{CH}_{3} \mathrm{CN}$ & - & traces & $>99$ & 69 \\
\hline 10 & $r a c-1$ & CAL-A on Celite ${ }^{\mathrm{e}}$ & $\mathrm{CH}_{3} \mathrm{CN}$ & - & traces & $>99$ & 75 \\
\hline
\end{tabular}

${ }^{a}$ Yield at the conversion where the reaction has stopped. ${ }^{b}$ CAL-A dialyzed from Novozym 735 solution before immobilized on Celite. See Experimental Section. ${ }^{c}$ Chirazyme L5 (20\%) in the presence of sucrose (12\%) and Celite (68\%). See ref. $12 \mathrm{~b} .{ }^{\mathrm{d}}$ Chirazyme L5 (20\%) in the presence of sucrose (12\%) and Celite (68\%). ${ }^{\mathrm{e}}$ Cat\#ICR-112 (20\%) in the presence of sucrose (12\%) and Celite $(68 \%)$. 
At least three reasons can be addressed to cause problems in the present DKR with CAL-A: (i) acetaldehyde or its condensation products which tend to form adducts with basic amino acid residues of the enzyme, (ii) stability of the Schiff base $\mathbf{8}$ or some of its adduct and (iii) ion pair formation of the substrate with an acid obtained when an acyl donor is enzymatically hydrolyzed by the residual water of the seemingly dry enzyme preparation. As to alternatives $(i)$ and (ii), the previous results with five microbial lipases suggest that acetaldehyde forms Schiff bases with basic amino acid residues of the enzymes and reacts into $\alpha, \beta$-unsaturated polyenals which may subsequently form stable Michael-adducts with the enzymes. ${ }^{22}$ Even though CAL-A was not included in the study, these results are evidently general to lipases. Indeed, small amounts of unidentified products were detected in the GC- or HPLC-chromatograms of the present DKRs with CAL-A. However, stopping of the acylations of rac-1 or $\mathbf{- 5}$ after $48 \mathrm{~h}$ with the Novozym 735 -based CAL-A on Celite cannot be attributed to acetaldehyde alone as in the previous work $^{12 \mathrm{~b}}$ Chirazyme L5 -based CAL-A on Celite effectively catalyzed especially the DKR of proline methyl ester $\left(e_{\mathrm{P}}=97 \%, 86 \%\right.$ yield after $\left.1 \mathrm{~h}, 25^{\circ} \mathrm{C}\right)$ under the otherwise same conditions.

On the other hand, it is apparent that the residual water may cause significant background hydrolysis of ester substrates and products. The ester functionalities in $\mathbf{1}$ and $\mathbf{5}$ are unlikely substrates to enzymatic hydrolysis as the narrow acyl binding pocket of CAL-A hardly accommodates the acyl part of the substrates. ${ }^{14}$ In the present work, the residual water hydrolyzed vinyl butanoate producing butanoic acid. The acid can form salt 10, precipitating the amine substrate out of the reaction mixture, and the salt pair with the amino groups of basic amino acid residues in the protein structure itself. The latter effect, affecting conformational changes, can cause differences in the CAL-A preparations obtained from Chirazyme L5 and Novozym 735. To minimize the salt pair formation one equivalent of triethylamine was added into the reaction mixture to capture the acid. On the other hand, to minimize the hydrolysis of vinyl butanoate and accordingly to better control the amount of releasing acetaldehyde, the DKR was performed in the presence of molecular sieves $(3 \AA)$. Considerably less substrate now disappeared (the sum $87 \%$ of the substrate and product yields compared to the sum $61 \%$, entries 3 and 4) while the product outcome otherwise was unchanged. When the reaction was repeated in the presence of larger pore size molecular sieves $(4 \AA)$ both the substrate and product yields stayed low (entry 5).

As a conclusion, the exceptional property of CAL-A to catalyze N-acylations of secondary amino groups in N-heterocyclic $\alpha$-amino acids connected to aldehyde-based racemization affords a potential DKR method. The method allows the transformations of racemic proline, pipecolic acid and 4- $N$-Boc-piperazine-2-carboxylic acid methyl esters into the N-acylated $S$ enantiomers at $86-88^{12 b}, 60-61^{12 b}$ and $60-75 \%$ yields, respectively. The present results address the importance of immobilization for the successful DKR. On the other hand, the history of the CAL-A is evidently important, even if the preparations are finally immobilized on Celite by the same method as in the present work. 


\section{Substrate requirements for CAL-A}

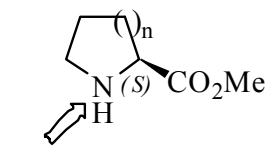

$11(\mathrm{n}=1)$

$\mathrm{c}=50 \%(\mathrm{t}=0.5 \mathrm{~h}), \boldsymbol{E}>\mathbf{1 0 0}$

$5(\mathrm{n}=2)$

c $=49 \%(\mathrm{t}=9 \mathrm{~h}), \boldsymbol{E}>\mathbf{1 0 0}$

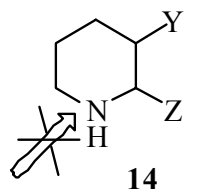

$\mathrm{Y}=\mathrm{H}, \mathrm{Z}=\mathrm{CH}_{2} \mathrm{OH}$

$\mathrm{Y}=\mathrm{CH}_{2} \mathrm{OH}, \mathrm{Z}=\mathrm{H}$

no reaction

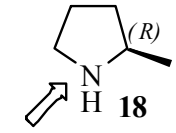

$\mathrm{c}=31 \%(\mathrm{t}=5 \mathrm{~d})$

$\boldsymbol{E}=\mathbf{2}$

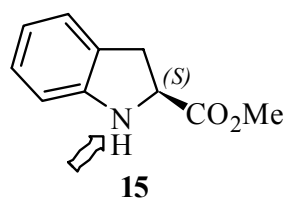

allyl 3-methoxyphenyl carbonate $\mathrm{c}=50 \%(\mathrm{t}=4 \mathrm{~h}), \boldsymbol{E}>\mathbf{2 0 0}$

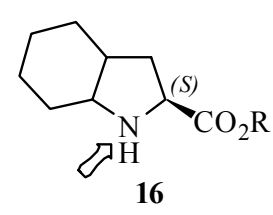

diallyl carbonate $\mathrm{R}=\mathrm{Me}: \mathrm{c}=12 \%(\mathrm{t}=48 \mathrm{~h}), \boldsymbol{E}>\mathbf{2 0 0}$ $\mathrm{R}=\mathrm{Bn}: \mathrm{c}=50 \%(\mathrm{t}=72 \mathrm{~h}), \boldsymbol{E}>\mathbf{2 0 0}$

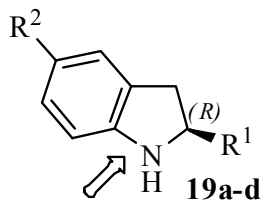

allyl 3-methoxyphenyl carbonate

a: $\mathrm{R}^{1}=\mathrm{Me}, \mathrm{R}^{2}=\mathrm{H}: \mathrm{c}=47 \%(\mathrm{t}=67 \mathrm{~h}), \boldsymbol{E}>\mathbf{2 0 0}$

b: $\mathrm{R}^{1}=\mathrm{Me}, \mathrm{R}^{2}=$ OMe: c $=51 \%(\mathrm{t}=20 \mathrm{~h}), \boldsymbol{E}>\mathbf{2 0 0}$

c: $\mathrm{R}^{1}=\mathrm{Me}, \mathrm{R}^{2}=\mathrm{F}: \mathrm{c}=50 \%(\mathrm{t}=20 \mathrm{~h}), \boldsymbol{E}>\mathbf{2 0 0}$

d: $\mathrm{R}^{1}=\mathrm{Ph}, \mathrm{R}^{2}=\mathrm{H}: \mathrm{c}=50 \%(\mathrm{t}=20 \mathrm{~h}), \boldsymbol{E}>\mathbf{2 0 0}$

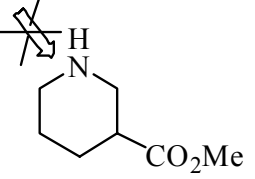

12<smiles>CC(=O)CC1CCCCN1C(C)C</smiles>

no reaction<smiles>CC(=O)C1NCCc2ccccc21</smiles>

17

no reaction

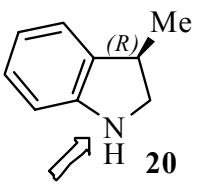

allyl 3-methoxyphenyl carbonate $\mathrm{c}=50 \%(\mathrm{t}=4 \mathrm{~h}), \boldsymbol{E}=\mathbf{6}$

Scheme 4. KR of of $N$-heterocyclic amines with 2,2,2-trifluoroethyl butanoate (unless otherwise stated) in TBME. Faster reacting enantiomers have been presented. ${ }^{12 \mathrm{a}-\mathrm{g}}$

Since the first papers on the CAL-A-catalyzed secondary N-acylation of proline methyl ester 11 and pipecolic acid methyl ester 5, ${ }^{12 a, b}$ many studies have widened the knowledge of the substrate scope of the enzyme related to the KR of compounds with heterocyclic secondary ring nitrogen (Scheme 4). ${ }^{12 \mathrm{c}-\mathrm{g}}$ These substrates include $\alpha$-amino esters 1, 5, 11 and 15-17, $\beta$-amino esters 2, 12 and 13 as well as other secondary amines 14 and 18-20. The substrate of the present paper, 4- $N$-Boc-piperazine-2-carboxylic acid methyl ester $\mathbf{1}$, together with structurally similar $\alpha$ amino esters 5, 11, 15 and $\mathbf{1 6}$ with the $S$-configuration are effectively accepted by CAL-A. The results also show that bicyclic indoline 15 and octahydroindole $16^{12 \mathrm{c}}$ rings are allowed but not bicyclic 17, methyl 1,2,3,4-tetrahydroisoquinoline-1-carboxylate (TIC-1) ${ }^{12 \mathrm{~d}}$. When piperidinering contains $-\mathrm{CH}_{2} \mathrm{OH} 14$ either in 2- or 3-positions, secondary $\mathrm{N}$-acylation does not take place. ${ }^{12 \mathrm{e}}$ Although the $\mathrm{N}$-acylated product was observed, it was formed through $\mathrm{O} \rightarrow \mathrm{N}$ acyl 
migration after the enzymatic $\mathrm{O}$-acylation. When carboxylic group is one carbon away from the amine nitrogen in $\beta$-amino esters 12 and 13, the $\mathrm{N}$-acylation does not take place. ${ }^{12 \mathrm{f}}$ Therefore, the enantioselective $\mathrm{N}$-acylation of $\mathrm{rac}-\mathbf{2}$ observed in this work was not expected. Evidently the presence of the Boc protected $\alpha$-amino group with possibilities to participate in hydrogen bonding or hydrophobic interactions with CAL-A makes the compound a good substrate. It is interesting to note that the $R$-enantiomer of $r a c-2$ is reactive, whereas in all other cases of Scheme 4 the opposite stereostructure reacts.

The KR of 2-methylpyrrolidine 18 and its analog 2-methylindoline 19a with 2,2,2trifluoroethyl butanoate in TBME was investigated in the current study using both Novozym 735 and Chirazyme L5 -based CAL-A on Celite as catalysts to compare the behavior of the secondary amines to $\alpha$-amino esters 11 and $\mathbf{1 5}$. When the ester functionality of $\mathbf{1 1}$ was replaced by methyl 18, both enantioselectivity and the reaction rate drastically dropped $(E=2, \mathrm{c}=31 \%$ in 5 days) while the aromatic ring in 19a contributed to the high enantioselectivity of the reaction. This indicates the importance of an electron rich structure (carbonyl group or benzene ring fused with pyrrolidine) in the substrate structure. The group of Gotor managed to enhance the reaction rate of 19a-d by using various carbonates as acyl donors. ${ }^{12 \mathrm{~g}}$ The shift of the asymmetric centre one carbon away from the ring nitrogen $\mathbf{2 0}$ causes a marked decrease on enantioselectivity $(E=$ $6){ }^{12 g}$

\section{Conclusions}

The present study describes an efficient CAL-A-catalyzed kinetic resolution of $N$-4-Bocpiperazine-2-carboxylic acid methyl ester ( $\mathrm{rac}$-1) where highly $S$-enantioselective $\mathrm{N}$-acylation of the secondary amino group with trifluoroethyl butanoate yielded both the substrate and the product enantiomers with $>99 \%$ ee. Similarly, the N-acylation of $N$-1-Boc-2piperazinecarboxylic acid methyl ester ( $\mathrm{rac}-2)$ took place with high enantioselectivity $(E=200)$ under the same conditions in spite of the opposite enantiopreference observed. The transformation of the kinetic resolution of $\mathrm{rac}-\mathbf{1}$ into the aldehyde-based dynamic one showed some potential, forming the amide product $(S)-3$ (ee $>99 \%$ ) at $75 \%$ yield from rac-1 in acetonitrile. By-product formation due to the use of acetaldehyde as a racemization catalyst lowered the yield from the theoretical $100 \%$ yield. However, potential of the method comes from the fact that acetaldehyde, the racemization catalyst, is formed in situ in the reaction mixture from the acyl donor. Thus, mostly used expensive chemical racemization catalysts which often need extremely dry and air-free reaction conditions can be avoided.

The obtained results with the literature data aid conceptualizing the substrate requirements for the secondary N-acylation by CAL-A. The structures so far studied encompass a pyrrolidine, piperidine or piperazine ring. Systematic studies with smaller or larger heterocyclic ring structures or with alicyclic secondary amines have not yet been reported. However, according to the present understanding, reaction rate and enantioselectivity of $\mathrm{N}$-acylation is clearly enhanced 
when carboxylic ester is attached to the asymmetric center next to the secondary nitrogen of the heterocyclic ring. Also the aromatic ring attached to the pyrrolidine ring may aid improving the enantioselectivity. As a conclusion, CAL-A is an appealing catalyst when resolutions based on the $\mathrm{N}$-acylation of the secondary ring nitrogens should be carried out.

\section{Experimental Section}

General. $N$-4- and N-1-Boc-piperazine-2-carboxylic acid methyl esters ( $r a c-1$ and -2) and enantiopure $(R)-\mathbf{2}$ were obtained from Fluorochem. Vinyl butanoate and diisopropyl ether were purchased from Fluka and J. T. Baker, respectively. Celite (filter agent, high-purity analytical grade, 167436), (R)- and rac-2-methylpyrrolidine 18, 2-methylindoline 19a, methyl pipecolinate hydrochloride, ethyl butanoate, acetonitrile, vinyl acetate and tert-butyl methyl ether were products of Aldrich. CAL-A solution (Novozym ${ }^{\circledR}$ 735) was obtained from Novozymes A/S. Lyophilized CAL-A preparations Chirazyme L5 and Cat\#ICR-112 were products of Roche and Biocatalytics, respectively. BCA solution, copper(II) sulfate perhydrate solution (4\%) and bovine serum albumin used for the determination of the protein content of Novozym 735 solution were products of Sigma. 2,2,2-Trifluoroethyl butanoate and acetate were synthesized from 2,2,2trifluoroethanol and the corresponding acid chloride or anhydride by the usual procedures.

The solution state ${ }^{1} \mathrm{H}$ and ${ }^{13} \mathrm{C}$ nuclear magnetic resonance (NMR) spectra were recorded using Bruker Avance $500 \mathrm{MHz}$ spectrometers. HRMS was measured in $\mathrm{ESI}^{+}$mode with a Bruker micrOTOF-Q quadrupole-TOF spectrometer. Optical rotations were determined by Perkin Elmer Polarimeter 341. The protein concentrations were determined by Perkin Elmer Lambda 650 UV/VIS spectrometer.

\section{Purification and immobilization of CAL-A}

The CAL-A solution (Novozym 735; $25 \mathrm{~mL}$ ) containing $40 \%$ of glycerol was diluted with phosphate buffer $(20 \mathrm{mM}, \mathrm{pH} 7,1: 1)$ and dialyzed against it $(1 \times 15 \mathrm{~L}$ and $1 \times 7.5 \mathrm{~L})$ and tris buffer $(20 \mathrm{mM}$, pH 7.8, $1 \times 7.5 \mathrm{~L})$. The volume of the obtained glycerol-free solution was 110 $\mathrm{mL}$. For the determination of the protein content, the BCA reagent solution (one volume of copper(II) sulfate solution and 50 volumes of BCA solution) and the lipase sample were mixed with vortex and incubated for 30 minutes at $35{ }^{\circ} \mathrm{C} .{ }^{23}$ After cooling to room temperature $\left(23{ }^{\circ} \mathrm{C}\right)$ the absorbance at $562 \mathrm{~nm}$ was measured using bovine serum albumin (0-100 $\mu \mathrm{g} /$ assay) as a standard. The protein content $0.0229 \mathrm{mg} \mathrm{ml}^{-1}$ corresponded to $2.52 \mathrm{mg}$ of protein for the total volume of $110 \mathrm{ml}$. Thus, Novozym 735 contained $10 \%$ of protein $(2.52 \mathrm{mg}$ protein $/ 25 \mathrm{~mL})$. However, all commercial CAL-A formulations contain protein impurities, which hampers determination of the real CAL-A content. ${ }^{13 \mathrm{e}}$ Therefore, the amounts of Celite and sucrose were calculated based on the lyophilization of $5 \mathrm{~mL}$ of glycerol-free lipase solution which gave 0.228 $\mathrm{g}$ of solid. To adsorb the lipase, Celite (3.88 g; 68\%) and sucrose $(0.684 \mathrm{~g} ; 12 \%)$ were subsequently added into $110 \mathrm{~mL}$ of purified Novozym 735 solution containing $1.14 \mathrm{~g} \mathrm{(20 \% )}$ of 
solid, and water was let to evaporate. Thus, $20 \%$ proportion of CAL-A used in our preparations contains contaminant proteins, buffer salts and possible stabilizers.

Chirazyme L5 and Cat\#ICR-112 were immobilized by dissolving $3.374 \mathrm{~g}$ of lyophilized CAL-A (20\%), 2.025 of sucrose (12\%) and $11.473 \mathrm{~g}$ of Celite $(68 \%)$ into $100 \mathrm{~mL}$ of tris buffer $(0.014 \mathrm{M}$; $\mathrm{pH}$ 7.8). The slurry was poured into a pot with large area followed by evaporation to dryness (3 days).

\section{Enzymatic reactions}

Typical reaction volume for enzymatic reactions was $1-3 \mathrm{~mL}$. Substrate $(0.050 \mathrm{M})$ and an acyl donor $(0.10-0.40 \mathrm{M})$ were dissolved in a solvent. In DKR studies, triethylamine $(0.050 \mathrm{M})$ was added as well. The addition of CAL-A preparation $\left(25-75 \mathrm{mg} \mathrm{mL}^{-1}\right)$ started the reaction. Quantitative analysis of the DKR reactions was performed by using hexadecane as an internal standard $(0.010 \mathrm{M})$. The progress of the reactions was followed by GC with Varian CP-ChirasilDEX CB (rac-5 and -19a) or J\&W Scientific Cyclosil-B (rac-18) columns, or by HPLC with Daicel Chiralcel OD-H column ( $r a c-1$ and -2). The samples $(0.1 \mathrm{ml})$ were taken at intervals and derivatized with acetic or trifluoroacetic anhydride (butanoate as an acyl donor) or butanoic anhydride (acetate as an acyl donor).

The determination of $E$ was based on the equation $E=\ln \left[(1-c)\left(1-e_{S}\right)\right] / \ln \left[(1-c)\left(1+e_{S}\right)\right] .{ }^{24}$ Using linear regression $E$ was achieved as the slope of a line. Unless otherwise stated, the calculation of $\mathrm{KR}$ conversion was based on the equation $\mathrm{c}=\mathrm{ee}_{\mathrm{S}} /\left(\mathrm{ee}_{\mathrm{S}}+\mathrm{ee}_{\mathrm{P}}\right)$.

\section{Preparative scale KR}

2,2,2-Trifluoroethyl butanoate $(618 \mu \mathrm{L} ; 4.09 \mathrm{mmol})$ and $\mathrm{rac}-1$ (0.5005 $\mathrm{g} ; 2.05 \mathrm{mmol})$ were dissolved in TBME (19.4 mL). Addition of CAL-A (0.5010 g; $\left.25 \mathrm{mg} \mathrm{mL}{ }^{-1}\right)$ started the reaction. The enzyme was filtered off after 3 hours at 50\% conversion. Purification by silicagel column chromatography (hexane/EtOAc $1: 1$ as an eluent) yielded $(R)-1(0.20 \mathrm{~g} ; 0.82 \mathrm{mmol}$; ee $99 \%$; $\left.[\alpha]_{\mathrm{D}}{ }^{25}-39.6^{\circ}\left(\mathrm{c} 1.0, \mathrm{CHCl}_{3}\right)\right)$ and $(S)-3\left(0.32 \mathrm{~g} ; 1.02 \mathrm{mmol}\right.$; ee $>99 \%$; $[\alpha]_{\mathrm{D}}{ }^{25}-22.4^{\circ}(\mathrm{c} 1.0$, $\left.\mathrm{CHCl}_{3}\right)$ ).

(R)-4-tert-butyloxypiperazine-2-carboxylic acid methyl ester $[(\boldsymbol{R})-1] .{ }^{1} \mathrm{H} \mathrm{NMR}(500.13 \mathrm{MHz}$, $\left.\mathrm{CDCl}_{3}, 25{ }^{\circ} \mathrm{C}\right): \delta=3.75\left(\mathrm{~s}, 3 \mathrm{H}, \mathrm{OCH}_{3}\right), 3.72\left(\mathrm{dd}, J_{3 \mathrm{a}-3 \mathrm{~b}}=-4.0 \mathrm{~Hz}, J_{3 \mathrm{a}-2}=3.5 \mathrm{~Hz}, 1 \mathrm{H}, \mathrm{H}-3 \mathrm{a}\right)$, $3.69\left(\mathrm{dd}, J_{3 \mathrm{~b}-2}=2.9 \mathrm{~Hz}, 1 \mathrm{H}, \mathrm{H}-3 \mathrm{~b}\right), 3.46$ (m, $\left.1 \mathrm{H}, \mathrm{H}-2\right), 3.08$ (m, $\left.1 \mathrm{H}, \mathrm{H}-6 \mathrm{a}\right), 3.04$ (dd, $J_{5 \mathrm{a}-5 \mathrm{~b}}=-$ $\left.4.0 \mathrm{~Hz}, J_{5 \mathrm{a}-6}=3.5 \mathrm{~Hz}, 1 \mathrm{H}, \mathrm{H}-5 \mathrm{a}\right), 3.01$ (dd, $\left.J_{5 \mathrm{~b}-6}=3.5 \mathrm{~Hz}, 1 \mathrm{H}, \mathrm{H}-5 \mathrm{~b}\right), 2.75$ (m, $\left.1 \mathrm{H}, \mathrm{H}-6 \mathrm{~b}\right), 2.15$ $(\mathrm{s}, 1 \mathrm{H}, \mathrm{NH}), 1.47\left(\mathrm{~s}, 9 \mathrm{H}, \mathrm{C}\left(\mathrm{CH}_{3}\right)_{3}\right) \mathrm{ppm} .{ }^{13} \mathrm{C} \mathrm{NMR}\left(500.13 \mathrm{MHz}, \mathrm{CDCl}_{3}, 25{ }^{\circ} \mathrm{C}\right): \delta=187.4$ $\left(\mathrm{C}=\mathrm{O}_{\text {ester }}\right), 154.6\left(\mathrm{C}=\mathrm{O}_{\text {carbamate }}\right), 80.0\left(\mathrm{C}\left(\mathrm{CH}_{3}\right)_{3}\right), 56.8(\mathrm{C}-2), 52.2\left(\mathrm{OCH}_{3}\right), 51.5(\mathrm{C}-5), 44.2(\mathrm{C}-3)$, $43.2(\mathrm{C}-6), 28.4\left(\mathrm{C}\left(\mathrm{CH}_{3}\right)_{3}\right)$ ppm.

(S)-1-Butanoyl-4-tert-butyloxypiperazine-2-carboxylic acid methyl ester $[(\boldsymbol{S})-3] \cdot{ }^{1} \mathrm{H}$ NMR $\left(500.13 \mathrm{MHz}, \mathrm{CDCl}_{3}, 25{ }^{\circ} \mathrm{C}\right): \delta=5.20\left(\mathrm{~d}, J_{2-3}=3.5 \mathrm{~Hz}, 1 \mathrm{H}, \mathrm{H}-2\right), 4.58\left(\mathrm{dd}, J_{3 \mathrm{a}-3 \mathrm{~b}}=-14.0 \mathrm{~Hz}, 1\right.$ H, H-3a), 4.43 (m, 1 H, H-6a), 3.73 (s, 3 H, OCH $), 3.67$ (m, 1 H, H-6b), 3.50 (m, 1 H, H-5a), 3.05 (dd, $1 \mathrm{H}, \mathrm{H}-3 \mathrm{~b}), 2.85(\mathrm{~m}, 1 \mathrm{H}, \mathrm{H}-5 \mathrm{~b}), 2.37$ (dd, $J_{\mathrm{CH} 2-\mathrm{CH} 2 \mathrm{CH} 3}=7.5 \mathrm{~Hz}, 2 \mathrm{H}, \mathrm{CH}_{2} \mathrm{CH}_{2} \mathrm{CH}_{3}$ ), $1.68\left(\mathrm{~m}, 2 \mathrm{H}, \mathrm{CH}_{2} \mathrm{CH}_{2} \mathrm{CH}_{3}\right), 0.98\left(\mathrm{~m}, 3 \mathrm{H}, \mathrm{CH}_{2} \mathrm{CH}_{2} \mathrm{CH}_{3}\right) \mathrm{ppm} .{ }^{13} \mathrm{C} \mathrm{NMR}\left(500.13 \mathrm{MHz}, \mathrm{CDCl}_{3}\right.$, 
$\left.25^{\circ} \mathrm{C}\right): \delta=173.5\left(\mathrm{C}=\mathrm{O}_{\text {ester }}\right), 171.2\left(\mathrm{C}=\mathrm{O}_{\text {amide }}\right), 154.1\left(\mathrm{C}=\mathrm{O}_{\text {carbamate }}\right), 80.4\left(C\left(\mathrm{CH}_{3}\right)_{3}\right), 55.9(\mathrm{C}-2)$, $52.8(\mathrm{C}-5), 52.4\left(\mathrm{OCH}_{3}\right), 51.9(\mathrm{C}-3), 42.6(\mathrm{C}-6), 35.3\left(\mathrm{CH}_{2} \mathrm{CH}_{2} \mathrm{CH}_{3}\right), 28.3\left(\mathrm{C}_{\left.\left(\mathrm{CH}_{3}\right)_{3}\right),}, 18.4\right.$ $\left(\mathrm{CH}_{2} \mathrm{CH}_{2} \mathrm{CH}_{3}\right), 13.9\left(\mathrm{CH}_{2} \mathrm{CH}_{2} \mathrm{CH}_{3}\right)$ ppm. HRMS: calcd. for $\mathrm{C}_{15} \mathrm{H}_{26} \mathrm{~N}_{2} \mathrm{O}_{5} \mathrm{Na}^{+}=[\mathrm{M}+\mathrm{Na}]^{+}$ 337.1734; found 337.1734 .

\section{Absolute configurations}

For the determination of absolute configuration of 1, $(R)-\mathbf{1}(0.19 \mathrm{~g} ; 0.78 \mathrm{mmol}$; ee $99 \%)$ obtained from the $\mathrm{KR}$ was dissolved in the mixture of water $(15 \mathrm{~mL})$ and $37 \% \mathrm{HCl}(3.2 \mathrm{~mL})$. The reaction took place overnight at room temperature and was thereafter refluxed for 4 hours. The product amino acid was filtered off, dried in a desiccator and characterized $\left(42.4 \mathrm{mg} ; 0.21 \mathrm{mmol} ;[\alpha]_{\mathrm{D}}{ }^{25}\right.$ $\left.+4.6^{\circ}\left(\mathrm{c} 1.0, \mathrm{H}_{2} \mathrm{O}\right)\right)$. The corresponding literature value has been reported $\left([\alpha]_{\mathrm{D}}{ }^{20}+4.74^{\circ}(\mathrm{c} 1.2\right.$, $\left.\mathrm{H}_{2} \mathrm{O}\right)$; ee $\left.99.2 \%\right)^{7}$

In the KR of rac-2, enantiopreference was based on the chiral GC chromatograms observed compared to that of the commercial reference compound, $(R)-\mathbf{2}$.

\section{Acknowledgements}

M.Sc. Paula Herttola is acknowledged for performing part of the experimental work. The authors thank the Academy of Finland for financial support (research grant \#121983, Fusing Biocatalytic and Chemocatalyzed Reaction Technologies).

\section{References}

1. Harris, E. W.; Ganong, A. H.; Monaghan, D. T.; Watkins, J. C.; Cotman, C. W. Brain Res. 1986, 382, 174.

2. Rossen, K.; Weissman, S. A.; Sager, J.; Askin, D.; Reider, P. J.; Volante, R. P. U. S. Patent $5723615,1998$.

3. Levin, J. I.; Chen, J. M.; Laakso, L. M.; Du, M.; Du, X.; Venkatesan, A. M.; Sandanayaka, V.; Zask, A.; Xu, J.; Xu, W.; Zhang, Y.; Skotnicki, J. S. Bioorg. Med. Chem. Lett. 2005, 15, 4345 .

4. Kelly, J. M.; Afonso, A. WO2007/084498 A1.

5. (a) Stingl, K.; Kottenhahn, M.; Drauz, K. Tetrahedron:Asymmetry 1997, 8, 979. (b) Aebischer, B.; Frey, P.; Haerter, H.-P.; Herrling, P. L.; Mueller, W.; Olverman, H. J.; Watkins, J. C. Helv. Chim. Acta 1989, 72, 1043. (c) Shiraiwa, T.; Shinjo, K.; Kurokawa, H. Bull. Chem. Soc. Jpn. 1991, 64, 3251.

6. Bruce, M. A.; St. Laurent D. R.; Poindexter, G. S.; Monkovic, I.; Huang, S.; Balasubramanian N. Synth. Comm. 1995, 25, 2673. 
7. Eichhorn, E.; Roduit, J.-P.; Shaw, N.; Heinzmann, K.; Kiener, A. Tetrahedron:Asymmetry 1997, 8, 2533.

8. Komeda, H.; Harada, H.; Washika, S.; Sakamoto, T.; Ueda, M.; Asano, Y. Eur. J. Biochem. 2004, 271, 1465.

9. Komeda, H.; Harada, H.; Washika, S.; Sakamoto, T.; Ueda, M.; Asano, Y. Eur. J. Biochem. 2004, 271, 1580.

10. Wu, G.; Zhao, H.; Luo, R. G.; Wei, D.; Malhotra, S. V. Enantiomer 2001, 6, 343.

11. Beard, T. M.; Turner, N. J. Chem. Commun. 2002, 246.

12. (a) Liljeblad, A.; Lindborg, J.; Kanerva, A.; Katajisto, J.; Kanerva, L. T. Tetrahedron Lett. 2002, 43, 2471. (b) Liljeblad, A.; Kiviniemi, A.; Kanerva, L.T. Tetrahedron 2004, 60, 671. (c) Alatorre-Santamaría, S.; Rodriguez-Mata, M.; Gotor-Fernández, V.; de Mattos, M. C.; Sayago, F. J.; Jiménez, A. I.; Cativiela, C.; Gotor, V. Tetrahedron:Asymmetry 2008, 19, 1714. (d) Paál, T. A.; Forró, E.; Liljeblad, A.; Kanerva, L. T.; Fülöp, F. Tetrahedron:Asymmetry 2007, 18, 1428. (e) Lundell, K.; Lehtinen, P.; Kanerva, L. T. Adv. Synth. Catal. 2003, 345, 790. (f) Liljeblad, A.; Kavenius, H.-M.; Tähtinen, P.; Kanerva, L. T. Tetrahedron:Asymmetry 2007, 18, 181. (g) Gotor-Fernández, V.; Fernández-Torres, P.; Gotor, V. Tetrahedron:Asymmetry 2006, 17, 2558.

13. (a) Kirk, O.; Christensen, M. W. Org. Process. Res. Dev. 2002, 6, 446. (b) Domínguez de María, P.; Carboni-Oerlemans, C.; Tuin, B.; Bargeman, G.; van der Meer, A.; van Gemert, R. J. Mol. Catal. B: Enzym. 2005, 37, 36. (c) Liljeblad, A.; Kanerva, L.T. Tetrahedron 2006, 62, 5831. (d) Li, X.-G.; Kanerva, L. T. Org. Lett. 2006, 8, 5593. (e) Liljeblad, A.; Kallio, P.; Vainio, M.; Niemi, J.; Kanerva, L. T. Org. Biomol. Chem. 2010, 8, 886. (f) Brem, J.; Liljeblad, A.; Paizs, C.; Tosa, M. I.; Irimie, F.-D.; Kanerva, L. T.; Tetrahedron:Asymmetry 2011, 22, 315.

14. (a) Ericsson, D. J.; Kasrayan, A.; Johansson, P.; Bergfors, T.; Sandström, A. G.; Bäckvall, J.-E.; Mowbray, S. L. J. Mol. Biol. 2008, 376, 109. (b) Engström, K.; Nyhlén, J.; Sandström, A. G.; Bäckvall, J.-E. J. Am. Chem. Soc., 2010, 132, 7038.

15. (a) Chen, S-T.; Huang, W-H.; Wang, K.-T. J. Org. Chem. 1994, 59, 7580. (b) Parmar, V. S.; Singh, A.; Bisht, K. S.; Kumar, N.; Belokon, Y. N.; Kochetkov, K. A.; Ikonnikov, N. S.; Orlova, S. A.; Tararov, V. I. Saveleva, T. F. J. Org. Chem. 1996, 61, 1223. (c) Hacking, M. A. P. J.; Wegman, M. A.; Rops, J.; van Rantwijk, F.; Sheldon, R. A. J. Mol. Catal. B: Enzymat. 1998, 5, 155. (d) Wegman, M. A.; Hacking, M. A. P. J.; Rops, J.; Pereira, P.; van Rantwijk, F.; Sheldon, R. A. Tetrahedron:Asymmetry 1999, 10, 1739. (e) Belokon, Y. N.; Kochetkov, K. A.; Plieva, F. M.; Ikonnikov, N. S.; Maleev, V. I.; Parmar, V. S.; Kumar, R.; Lozinsky, V. I. Appl. Biochem. Biotechnol. 2000, 84, 97. (f) Schichl, D. A.; Enthaler, S.; Holla, W.; Riermeier, T.; Kragl, U.; Beller, M. Eur. J. Org. Chem. 2008, 3506.

16. (a) Stirling, M.; Blacker, J.; Page, M. I. Tetrahedron Lett. 2007, 48, 1247. (b) Turner, N. J. Curr Opin. Chem. Biol. 2010, 14, 115.

17. El Blidi L.; Vanthuyne, N.; Siri, D.; Gastaldi, S.; Bertrand, M. P.; Gil, G. Org. Biomol. Chem. 2010, 8, 4165. 
18. Servi, S.; Tessaro, D.; Pedrocchi-Fantoni, G. Coord. Chem. Rev. 2008, 252, 715.

19. (a) Yamada, S.; Hongo, C.; Yoshioka, R. and Chibata, I. J. Org. Chem. 1983, 48, 843. (b) Barry, L. G.; Pugnière, M.; Castro, B.; Previero, A. Int. J. Peptide Protein Res. 1993, 41, 323. (c) Grigg, R.; Gunaratne, H. Q. N. Tetrahedron Lett. 1983, 24, 4457.

20. Calculated with ACE acidity and basicity calculator, available online at http://aceorganic.pearsoncmg.com/epoch-plugin/public/pKa.jsp.

21. Rios, A.; Crugeiras, J.; Amyes, T. L.; Richard, J. P. J. Am. Chem. Soc. 2001, 123, 7949.

22. Franken, B.; Eggert, T.; Jaeger, K. E.; Pohl, M. BMC Biochemistry 2011, 12:10.

23. (a) Smith, P. K.; Krohn, R. J.; Hermanson, G. T.; Mallia, A. K.; Gartner, F. H.; Provenzano, M. D.; Fujimoto, E. K.; Goeke, N. M.; Olson, B. J.; Klenk, D. C. Anal. Biochem. 1985, 150, 76. (b) Wiechelman, K. J., Braun, R. D.; Fitzpatrick, J. D. Anal. Biochem. 1988, 175, 231.

24. Chen, C.-S.; Fujimoto, Y.; Girdaukas, G.; Sih, C. J. J. Am. Chem. Soc., 1982, 104, 7294. 